\title{
Molecular analyses and reproductive structure to verify the generic relationships of Hypnea and Calliblepharis (Cystocloniaceae, Gigartinales), with proposal of $C$. saidana comb. nov.
}

\author{
Mi Yeon Yang and Myung Sook Kim* \\ Department of Biology, Jeju National University, Jeju 63243, Korea
}

The genera Hypnea and Calliblepharis of the family Cystocloniaceae are discriminated by their female reproductive structure, especially in the formation of carposporangia and gonimoblasts. Hypnea saidana, once classified based on obsolete evidence, has not been studied phylogenetically using molecular analysis and detailed reproductive structure though it shares many morphologic features with the genus Calliblepharis. To provide better understanding of generic relationship of H. saidana with Hypnea and Calliblepharis, we carried out molecular analyses using the nuclear-encoded small subunit ribosomal DNA (SSU) and chloroplast-encoded large subunit of the RuBisCO $(r b c \mathrm{~L}$ ), and exact morphological observations focusing on the reproductive structures of wild specimens. Our molecular phylogeny showed that H. saidana is closely related to Calliblepharis, but distinct from the clade of Hypnea. Female reproductive structure of $H$. saidana characterized by upwardly developing chains of carposporangia, central reticulum of cell, and gonimoblast filaments not connected to the pericarp provides definite evidence to assign the taxonomic position of this species to Calliblepharis. Based on our combined molecular and morphological analyses, we have proposed Calliblepharis saidana comb. nov., expanding the distribution of Calliblepharis habitat from the eastern Atlantic South Africa, the northern Indian Ocean, Australasia, and Brazil to the western Pacific Ocean.

Key Words: Calliblepharis saidana comb. nov.; Cystocloniaceae; Hypnea; molecular phylogeny; reproductive structure; taxonomy

\section{INTRODUCTION}

The family Cystocloniaceae Kützing (Order Gigartinales F. Schmitz) includes ca. 100 species, in 13 genera that are characterized by uniaxial, terete or flat thalli, filamentous or pseudoparenchmatous medulla, zonately divided tetrasporangia, and procarps with 3- or 4-celled carpogonial branches (Womersley 1994, Saunders et al. 2004, Guiry and Guiry 2017). Hypnea J. V. Lamouroux, the most speciose genus in the family with 62 species, generally has terete thalli that are erect or entangled (Guiry and Guiry 2017), but their male and female structures are inadequately understood (Kylin 1930, Mshigeni 1976, Vázquez-Delfín et al. 2016). Recent molecular studies have confirmed Hypnea as a strongly supported monophyletic group that is closely related to the genus Calliblepharis Kützing (Saunders et al. 2004, Geraldino et al. 2010).

Although the inclusion of molecular data has become commonplace in modern taxonomy (Yang et al. 2015,
(9) $\$$ This is an Open Access article distributed under the terms of the Creative Commons Attribution Non-Commercial License (http://creativecommons.org/licenses/by-nc/3.0/) which permits unrestricted non-commercial use, distribution, and reproduction in any medium, provided the original work is properly cited.
Received January 15, 2017, Accepted May 15, 2017

*Corresponding Author

E-mail: myungskim@jejunu.ac.kr

Tel: +82-64-754-3523, Fax: +82-64-756-3541 
Calderon and Boo 2016, Won et al. 2016, Yang and Kim 2016), reproductive structures have remained important diagnostic characteristics for differentiating many genera in the order Gigartinales (Hommersand et al. 1999, DíazTapia et al. 2013). For instance, Hypnea and Calliblepharis can be readily distinguished each other by female reproductive structures even if they share many vegetative features in common. Although carposporangia are formed as terminal cells of each gonimoblast filament in both Hypnea and Calliblepharis, each gonimoblast filament produce only one carposporangium in Hypnea, while Calliblepharis exhibits in chains. Also, numerous filaments link the gonimoblasts and the pericarp in Hypnea, but these filaments are absent in Calliblepharis (Kylin 1928, 1930, 1932).

Hypnea saidana Holmes is a red algae characterized by complanate and more or less dichotomous thalli with alternate branches that are mostly curved bearing short branchlets (Holmes 1895, Okamura 1909, Tanaka 1941). First described based on the material collected from Enoshima, Japan (Holmes 1895), it has remained one of the most taxonomically well characterized species in Korea and Japan. However, recent development of phylogenetic methodology made the need for improving $H$. saidana taxonomy based on obsolete evidence urgent. For example, current classification of $H$. saidana lack the consideration of reproductive structure, according to Shin and Boo (1994) which is essential for proper reassessment due to its similarity to Calliblepharis in terms of vegetative features, i.e., complanate thalli, dispersed surface cells, and numerous pit connections between medullary cells. In addition, recently described taxa, Calliblepharis hypneoides Díaz-Tapia, Bárbara \& Hommersand and C. psammophilus D'Archino \& W. A. Nelson, were assigned to Calliblepharis based on observations of the female structures even though they superficially resembled the species of Hypnea (Díaz-Tapia et al. 2013, D'Archino et al. 2015).

However, taxonomy based on the reproductive characteristics, though effective, poses a serious problem in identifying appropriate specimens during the asexual stage of red algae (Sherwood et al. 2010) and molecular procedures have been used to circumvent this problem. In fact, these molecular procedures have rapidly redefined phylogenetic relationships among Gigartinales taxa recently (Yang et al. 2015, Calderon and Boo 2016, Yang and Kim 2016). Several molecular studies have also been performed to verify the phylogenetic relationships of species within genus Hypnea itself (Geraldino et al. 2009, 2010, D'Archino et al. 2015).
These considerations clearly reveal the possibility that current taxonomy of $H$. saidana based on vegetative morphology could be mistaken as Díaz-Tapia et al. (2013) mentioned, although some red algal species can be assigned to Hypnea based on morphology, they could be assigned equally well to Calliblepharis. This implies that phylogeny regarding species of these two genera requires highly refined morphological characterization and molecular analysis using diverse species enough to allow inter-genera comparison within the order Gigartinales.

In this study, we tried to reexamine H. saidana phylogeny (Okamura 1909, Tanaka 1941, Shin and Boo 1994, Yamagishi and Masuda 1997) to put it on a more accurate taxonomic position. As mentioned above, the family Cystocloniaceae requires the concentrated study using both molecular and morphological data to infer their phylogenetic relationships. Therefore, we put special emphasis on precise morphological characterization of reproductive structures, which was possible through direct observation of female and male reproductive structures of wild specimens. We also noted that our morphological characterization tightly supported our molecular analyses using the combined alignments of the nuclear-encoded small subunit ribosomal DNA (SSU) and chloroplast-encoded large subunit of the RuBisCO gene ( $r b c \mathrm{~L})$ sequences.

\section{MATERIALS AND METHODS}

\section{Specimen preparation}

Samples of Calliblepharis saidana were collected in Korea and Japan during 2012-2016 (Table 1). Vegetative specimens were collected year-round, but female / male specimens were sampled only in the Jeju (August 2015) and Wando (January 2016), Korea. Field collections were kept fresh in a cool box containing seawater and transported to the laboratory. Voucher specimens were deposited to the Herbarium of Jeju National University and the National Institute of Biological Resources (NIBRRD0000000005), Incheon, Korea. Sub-samples were dried in silica gel for molecular analyses or in $5 \%$ formalin / seawater for morphological observations. Sections were hand cut using a razor blade or prepared using a benchtop freezing microtome (MFS No. 222; Nippon Optical Works, Tokyo, Japan). Section samples were stained with $1 \%$ aniline blue, acidified with $1 \% \mathrm{HCl}$ and mounted in a $40 \%$ corn syrup solution. We also treated with Wittmann's (1965) aceto-iron-hematoxylin-chloral hydrate, and mounted in 50\% Hoyer's mounting medium (Lin et 
al. 2009). Photomicrographs were captured using the EOS 600 D digital camera (Canon, Tokyo, Japan) mounted on the BX 43 microscope (Olympus, Tokyo, Japan). Images of pressed specimens were captured using the $\mathrm{D} 80$ camera (Nikon, Tokyo, Japan). The digitized images were imported into Adobe Photoshop (ver. 6.1) software and edited to produce the photographic plates.

\section{DNA extraction and sequencing}

DNA was extracted from small portions of dried thalli in liquid nitrogen using the DNeasy Plant Mini kit (Qiagen, Hilden, Germany) following manufacturer's instructions. The extracted DNA was stored at $-20^{\circ} \mathrm{C}$, and used to amplify chloroplast $r b c \mathrm{~L}$ and nuclear SSU rDNA. The primer combination F7-R898 and R762-R1442 was used for $r b c \mathrm{~L}$ (Gavio and Fredericq 2002, Kim et al. 2010) and G01-G14 and G04-G07 for SSU rDNA (Saunders and Moore 2013), respectively. Polymerase chain reaction (PCR) amplification was performed in the Swift MaxPro thermal cycler (ESCO, Singapore) using AccuPower PCR Premix (Bioneer, Daejeon, Korea). PCR products were pu- rified using the Accuprep PCR Purification Kit (Bioneer) following manufacturer's instructions. Sequencing of the forward and reverse strands of the purified PCR products was performed commercially by Macrogen (Seoul, Korea). Two electropherogram outputs from each sample were processed using Chromas version 1.45 software (Technelysium Pty Ltd., South Brisbane, QLD, Australia).

\section{Phylogenetic analyses}

Sequences generated in this study and sequences obtained from GenBank were aligned using Clustal O software (Sievers et al. 2011), and adjusted visually. We used sequences of 24 Gigartinales taxa for SSU and 41 Gigartinales taxa for $r b c L$, respectively. The sequence alignment of $r b c \mathrm{~L}$ (a protein-encoding gene) was unequivocal due to the absence of indels while ambiguous sites of SSU rDNA were trimmed for the alignment. The SSU and $r b c \mathrm{~L}$ alignments were concentrated and a combined data set were analyzed using maximum likelihood (ML) and Bayesian inference (BI) mentioned the following methods.

To infer phylogenetic relationships, we conducted

Table 1. Collection information of Calliblepharis saidana comb. nov. used in this study

\begin{tabular}{|c|c|c|}
\hline Collection information & Voucher & GenBank accession No. \\
\hline Aedo, Namhae, Korea; May 19, 2012; $34^{\circ} 41^{\prime} 31^{\prime \prime}$ S, $128^{\circ} 02^{\prime} 06^{\prime \prime}$ E; subtidal & Gigar017 & MF083596 $^{\mathrm{a}}$ \\
\hline Biyangdo, Jeju, Korea; Jul 15, 2015; $33^{\circ} 24^{\prime} 51^{\prime \prime}$ S, $126^{\circ} 13^{\prime} 45^{\prime \prime}$ E; subtidal & Gigar $425^{\mathrm{b}}$ & MF083583 $^{\mathrm{a}}$ \\
\hline 우; Biyangdo, Jeju, Korea; Jul 15, 2015; $33^{\circ} 24^{\prime} 51^{\prime \prime}$ S, $126^{\circ} 13^{\prime} 45^{\prime \prime}$ E; subtidal & Gigar426 & $\begin{array}{l}\text { MF083582 }^{\mathrm{a}} \\
\text { MF083599 }^{\mathrm{c}}\end{array}$ \\
\hline Chujado, Jeju, Korea; Aug 17, 2012; $33^{\circ} 56^{\prime} 40^{\prime \prime}$ S, $126^{\circ} 19^{\prime} 51^{\prime \prime}$ E; intertidal & Gigar115 & MF083594 ${ }^{\mathrm{a}}$ \\
\hline Daesambudo, Yeosu, Korea; Jul 31, 2013; $34^{\circ} 03^{\prime} 33^{\prime \prime}$ S, $127^{\circ} 23^{\prime} 03^{\prime}$ E; subtidal & Gigar195 & MF083595 \\
\hline Ganjeolot, Ulsan, Korea; Jan 12, 2012; 35² $21^{\prime} 35^{\prime \prime}$ S, $129^{\circ} 21^{\prime} 43^{\prime \prime}$ E; intertidal & Gigar129 ${ }^{\mathrm{b}}$ & MF083597 ${ }^{\mathrm{a}}$ \\
\hline Gijang, Busan, Korea; Jul 26, 2012; $35^{\circ} 11^{\prime} 24^{\prime \prime}$ S, $129^{\circ} 13^{\prime} 25^{\prime \prime}$ E; intertidal & Gigar134 & MF083592 $^{\mathrm{a}}$ \\
\hline Jakdo, Yeosu, Korea; Jul 26, 2012; 34²4'53" S, $127^{\circ} 54^{\prime} 14^{\prime \prime}$ E; subtidal & Gigar016 & MF083598 $^{\mathrm{a}}$ \\
\hline Munseom, Jeju, Korea; Jan 17, 2016; $33^{\circ} 13^{\prime} 40^{\prime \prime}$ S, $126^{\circ} 34^{\prime} 02^{\prime \prime}$ E; subtidal & $\begin{array}{c}\text { Gigar096 }^{\mathrm{b}} \\
\text { (NIBRRD0000000005) }\end{array}$ & MF083589 \\
\hline Seopseom, Jeju, Korea; Jan 23, 2014; 33¹3'46" S, $126^{\circ} 35^{\prime} 46^{\prime \prime}$ E; subtidal & Gigar263 & MF083590 ${ }^{\mathrm{a}}$ \\
\hline Songjeong, Busan, Korea; Dec 20, 2012; $35^{\circ} 10^{\prime} 39^{\prime \prime}$ S, $129^{\circ} 12^{\prime} 09^{\prime \prime}$ E; subtidal & Gigar098 & MF083593 $^{\mathrm{a}}$ \\
\hline$\oplus$; Wando, Korea; Jan 16, 2013; $34^{\circ} 17^{\prime} 46^{\prime \prime}$ S, $126^{\circ} 42^{\prime} 05^{\prime \prime}$ E; drift & Gigar135 & MF083591 $^{\mathrm{a}}$ \\
\hline$\oplus$; Wando, Korea; Jan 16, 2013; $34^{\circ} 17^{\prime} 46^{\prime \prime}$ S, $126^{\circ} 42^{\prime} 07^{\prime \prime}$ E; drift & Gigar533 ${ }^{\mathrm{b}}$ & MF083580 \\
\hline 우; Wando, Korea; Jan 24, 2016; $34^{\circ} 17^{\prime} 46^{\prime \prime}$ S, $126^{\circ} 42^{\prime} 07^{\prime \prime}$ E; drift & Gigar535 & MF083579 \\
\hline ठ'; Wando, Korea; Jan 24, 2016; $34^{\circ} 17^{\prime} 46^{\prime \prime}$ S, $126^{\circ} 42^{\prime} 07^{\prime \prime}$ E; drift & Gigar534 & MF083578 ${ }^{\mathrm{a}}$ \\
\hline Enoshima beach, Fujisawa, Japan; Mar 28, 2014; $35^{\circ} 18^{\prime} 25^{\prime \prime}$ S, $139^{\circ} 25^{\prime} 15^{\prime \prime}$ E; drift & Gigar308 $8^{\mathrm{b}, \mathrm{d}}$ & $\begin{array}{l}\text { MF083585 }^{\mathrm{a}} \\
\text { MF083600 }^{\mathrm{c}}\end{array}$ \\
\hline Enoshima beach, Fujisawa, Japan; Mar 28, 2014; $35^{\circ} 18^{\prime} 25^{\prime \prime}$ S, $139^{\circ} 25^{\prime} 15^{\prime \prime}$ E; drift & Gigar309 $9^{\mathrm{b}, \mathrm{d}}$ & MF083584 $^{\mathrm{a}}$ \\
\hline Ohara, Isumi, Chiba, Japan; Mar 24, 2014; $35^{\circ} 15^{\prime} 10^{\prime \prime}$ S, $140^{\circ} 24^{\prime} 26^{\prime \prime}$ E; drift & Gigar307 & MF083587 ${ }^{\mathrm{a}}$ \\
\hline 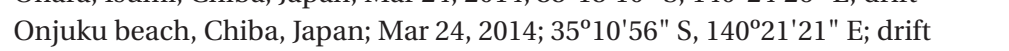 & Gigar306 & MF083588 \\
\hline Ubara beach, Katsuura, Japan; Mar 22, 2014; 3508'12" S, $140^{\circ} 16^{\prime} 26^{\prime \prime}$ E; drift & Gigar305 & MF083586 $^{\mathrm{a}}$ \\
\hline Ubara beach, Katsuura, Japan; Mar 22, 2014; $35^{\circ} 08^{\prime} 12^{\prime \prime}$ S, $140^{\circ} 16^{\prime} 26^{\prime \prime}$ E; drift & Gigar510 & MF083581 $^{\mathrm{a}}$ \\
\hline
\end{tabular}



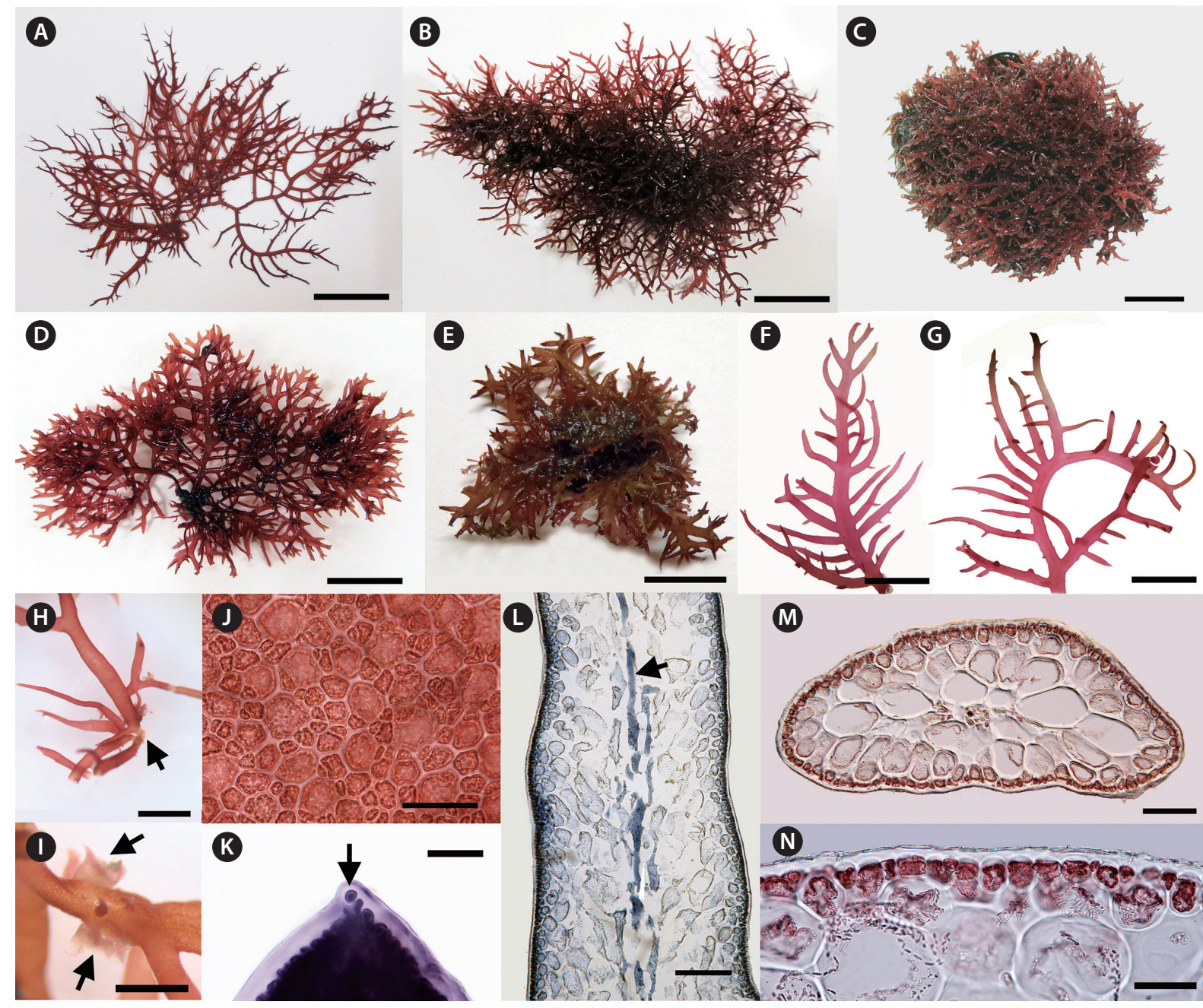

Fig. 1. Vegetative morphology of Calliblepharis saidana comb. nov. (A) Drift sample from the type locality, Enoshima, Japan (Mar 28, 2014, voucher = Gigar308). (B) Drift sample from Wando, Korea (Jan 24, 2016, voucher = Gigar533). (C) Intertidal sample collected from Ganjeolot, Korea (Jan 12, 2012, voucher = Gigar129). (D) Subtidal sample collected from Munseom, Korea (Jan 17, 2016, voucher = Gigar096). (E) Subtidal sample from Daesambudo, Yeosu, Korea (Jul 31, 2013, voucher = Gigar195). (F \& G) Apical part of an erect branch with numerous alternate branchlets and a secund one with outward branchletss. (H) Basal part showing a small discoid holdfast (arrow). (I) Several projections (arrows) on a branch. (J) Surface view of a thallus showing angular to rounded cortical cells. (K) Apical cell (arrow) of a thallus tip. (L) Longitudinal section of a thallus median part showing an axial filament (arrow) with several central elongated cells. (M) Cross-section of a branch showing two to four rounded medullary cells. (N) Layer of rounded cortical cells. Scale bars represent: A \& B, 2 cm; C-G, $1 \mathrm{~cm} ; \mathrm{H}, 5 \mathrm{~mm} ; \mathrm{l}, 2 \mathrm{~mm} ; \mathrm{J}, \mathrm{K} \& \mathrm{~N}, 50 \mu \mathrm{m} ; \mathrm{L} \& \mathrm{M}, 200 \mu \mathrm{m}$.

ML analysis using the GTR $+\Gamma$ evolutionary model ('-m GTRGAMMA' option) in RAxML (Stamatakis 2006). To identify the best-fit tree, we performed 200 independent tree searches using 'the number of runs' option. We ran 1,000 replications in RAxML software using the same setting to generate bootstrap support value of monophyletic nodes (MLBt). We also performed the BI in MrBayes v.3.2.1 (Ronquist et al. 2012) using the metropolis-coupled Markov Chain Monte Carlo simulations with the GTR $+\Gamma$ model to select the most appropriate phylogenetic tree. For two independent runs, we computed $2 \times 10^{6}$ generations with four chains, and sampled the trees every 100 generations. The burn-in point was identified graphically by tracking the likelihoods when the plateaued. Eventually, total 29,000 trees sampled in the stationary state were used to infer Bayesian posterior probabilities (BPP).

\section{RESULTS}

\section{Morphology of Calliblepharis saidana}

We collected Calliblepharis saidana from lower intertidal to subtidal zones where plants were attached 


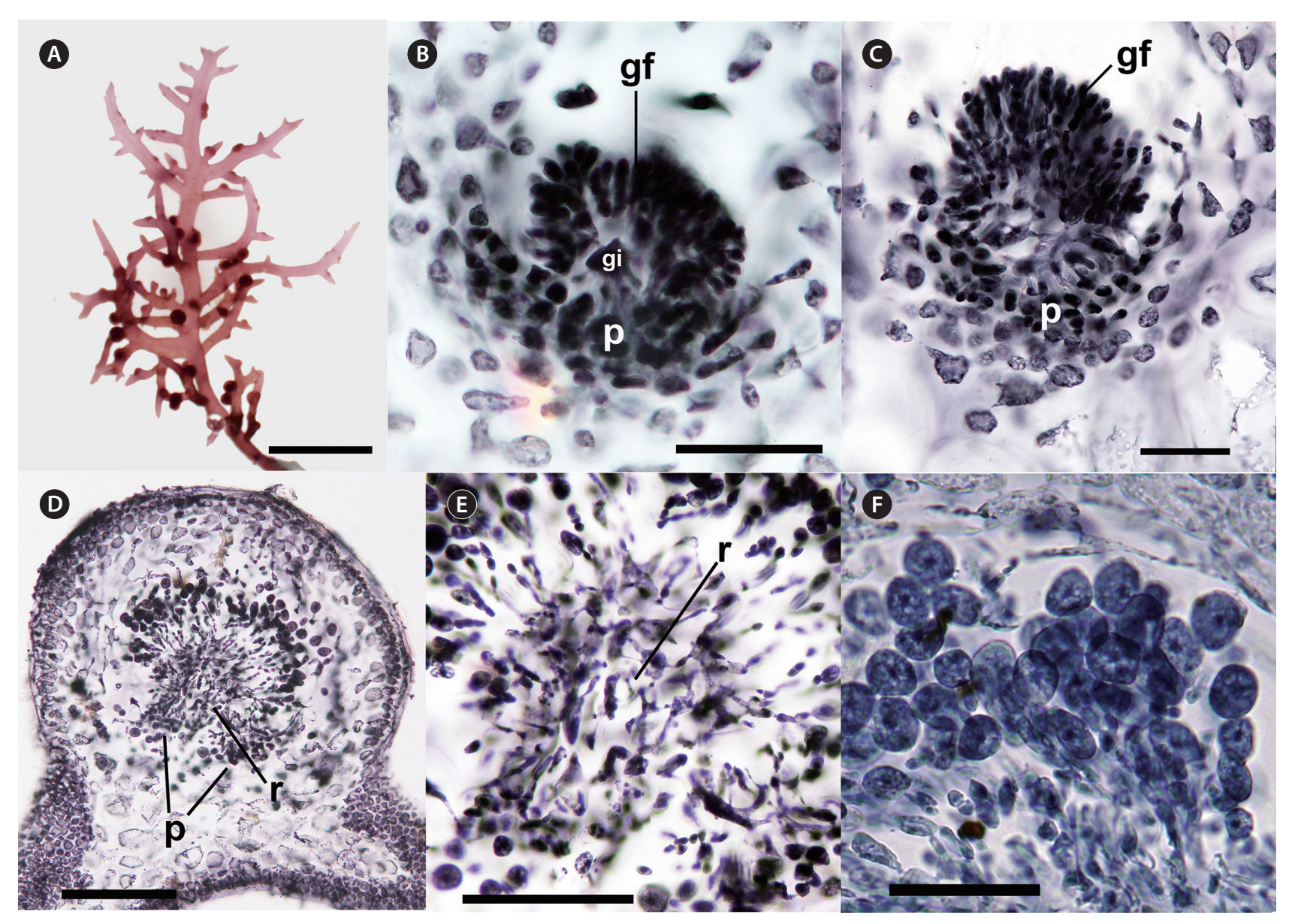

Fig. 2. Female reproductive structure of Calliblepharis saidana comb. nov. (voucher = Gigar425, 535). (A) Cystocarps formed on the base of branches or branchlets. (B \& C) Placenta (p) were developed inwardly from the gonimoblast initial (gi) at the center of cystocarp while gonimoblast filaments ( $\mathrm{g} f$ ) were produced at the outward location. (D) Transverse section of a cystocarp showing its sessile shape without ostiole. Central reticulum ( $r$ ) and basal placenta $(p)$ positions are marked. (E) Central reticulum ( $r$ ) composed of interconnected filaments. ( $F$ ) Chains of carposporangia. Scale bars represent: $A, 2 \mathrm{~cm} ; \mathrm{B}, \mathrm{C} \& \mathrm{E}, 100 \mu \mathrm{m} ; \mathrm{D}, 200 \mu \mathrm{m} ; \mathrm{F}, 50 \mu \mathrm{m}$.

to small pebbles, shellfish, other seaweeds, or drifted near the shoreline. Thalli of $C$. saidana were erect, compressed, 2-8 $\mathrm{cm}$ tall, 0.5-2.0 $\mathrm{mm}$ wide, and 400-850 $\mu \mathrm{m}$ thick, formed cartilaginous rounded clumps (Fig. 1A-E, L \& M). Branches appeared dichotomous or alternate of erect thalli or unilaterally in outward side of secund thalli. They were usually curved, tapered to points, and bore short branchlets. Branching took place most often in a single plane but sometimes in three dimensional space (Fig. 1F \& G). Holdfasts were discoid and multiple thalli arose from a single holdfast (Fig. 1H). Small projections attached to the substratum or adjacent branches were observed in thalli and branches (Fig. 1I).

On a surface view, cortical cells of a thallus were of various convex polygonal shapes and they did not form distinct rosettes (Fig. 1J). A thallus grew uniaxially initiated by a spearheading apical cell (Fig. 1K). It progressed through oblique divisions producing newly differentiated apical cells in alternating sides of growth axis. Longitudinal sections of the mid-frond (Fig. 1L) showed an axial filament, the trace of apical cell strand during growth, surrounded by elongated cells linked through secondary pit-connections. In the cross-sectional view, the central core of axial filament and periaxial cells were surrounded by two to four layers of large, rounded medullary cells measured 90-280 × 85-160 $\mu \mathrm{m}$ (Fig. 1M). The cortex consisted of a layer of rounded or cuboidal cells with 10-30 $\mu \mathrm{m}$ in diameter (Fig. $1 \mathrm{~N}$ ).

Cystocarps with gonimoblast initial, gonimoblast filaments, and placenta were formed inside branches and branchlets first and protruded through the cortex near their bases or sprouting points during maturation (Fig. 2A-D). When fully matured, they were sessile, subglobose with 600-800 $\mu \mathrm{m}$ in diameter encased in a thick pericarp 

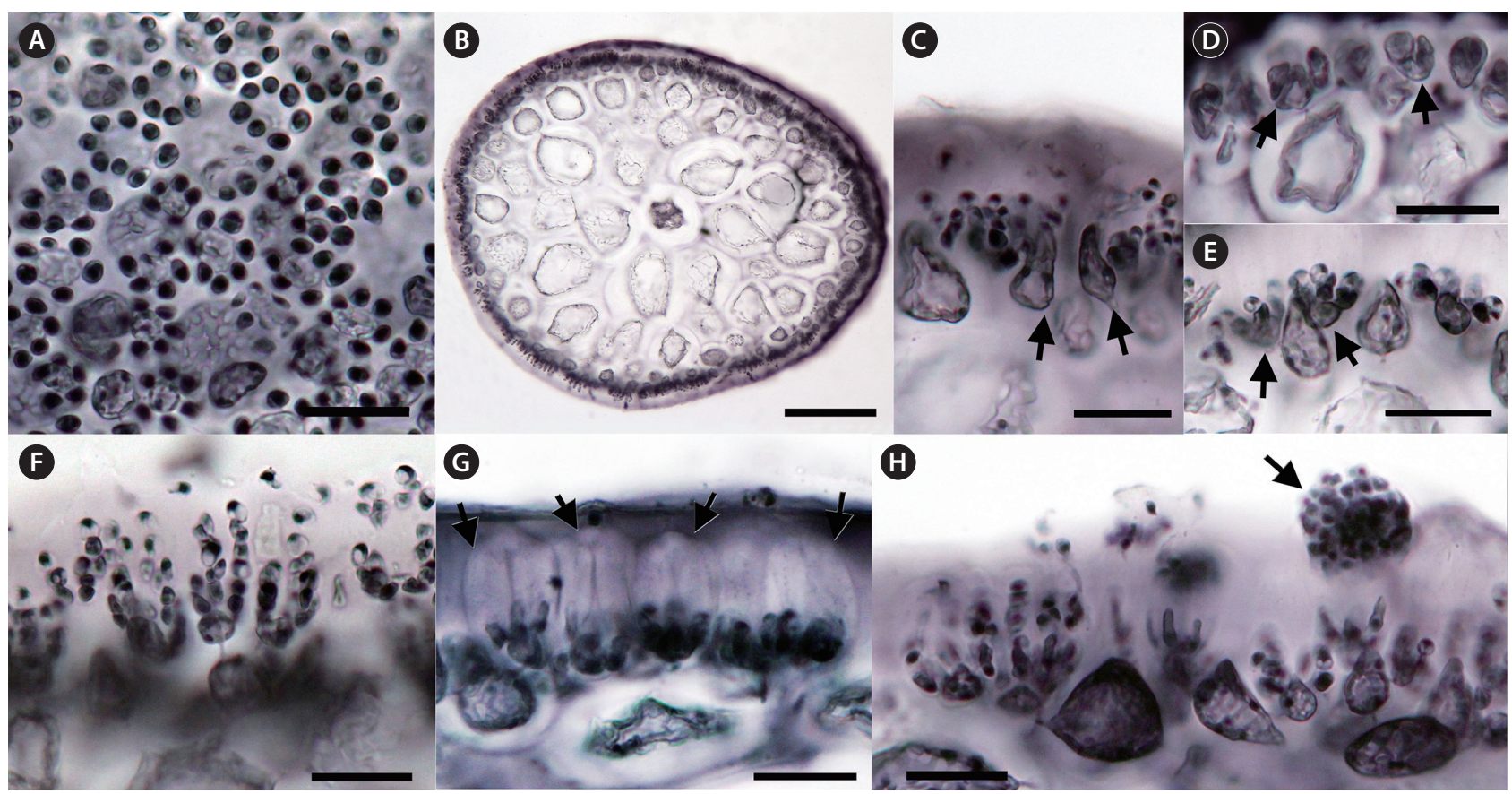

\section{G}

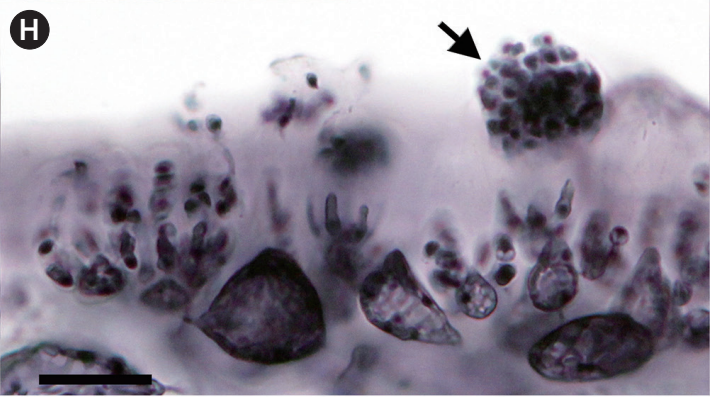

Fig. 3. Male reproductive structure of Calliblepharis saidana comb. nov. (voucher $=$ Gigar534). (A) Surface view of a thallus forming spermatia dyed dark. (B) Cross-section of a spermatangial branchlet covered by gelatinous matrix. (C) Modified cortical cells (arrows) producing spermatangial mother cells. (D \& E) Spermatangial mother cells (arrows) produce spermatia after cleavage. (F) Spermatangial filaments with up to seven spermatia stacked up at respective terminals. (G) Mature spermatangia enclosed by antheridial walls (arrows). (H) Release of spermatia accumulated in the upper part of antheridial wall (arrow). Scale bars represent: A \& C-H, $20 \mu \mathrm{m} ; \mathrm{B}, 100 \mu \mathrm{m}$.

without any ostiole (Fig. 2D). Nutritive placentae were generated at inward position from gonimoblast initial (Fig. 2B). Gonimoblast filaments were developed outwardly from gonimoblast initial and progressively turned into carposporangial chains (Fig. 2B-D). Small, interconnected cells between gonimoblasts and placenta formed a reticulum (Fig. 2D \& E). Mature globose carposporangia of 15-30 $\mu \mathrm{m}$ diameter piled up just outside the gonimoblast reticulum (Fig. 2F).

The spermatangia formed sori on branches and branchlets. Surface views of male plants showed rounded spermatia with 3-5 $\mu \mathrm{m}$ in diameter (Fig. 3A). A gelatinous matrix covered the reproductive portion of the thallus (Fig. 3B). Some of cortical cells became elongated (Fig. 3C), formed spermatangial mother cells (Fig. 3D), and produced spermatia (Fig. 3D-F). Spermatia existed in chains stacked up to seven cells (Fig. 3F). The mature antheridium was enclosed in a thick wall cushioned by an interposed gelatinous layer (Fig. 3G). Matured spermatia broke free from spermatangial chains, aggregated at the apex of the wall, and released through an apical split in the antheridial wall (Fig. 3G \& H).

Tetrasporangia formed sori covering the basal and mid portions of short cylindrical branches (Fig. 4A-C). Tet- rasporangia were initiated from modified cortical cells which bore lateral cells connected through pit connections (Fig. 4D \& E). After rounds of successive zonate division, tetrasporangia with 4 compartments appeared (Fig. $4 \mathrm{~F} \& \mathrm{G})$. Mature tetrasporangia were $15-30 \mu \mathrm{m}$ in diameter and 60-70 $\mu \mathrm{m}$ in length (Fig. $4 \mathrm{H} \& \mathrm{I}$ ).

\section{Molecular phylogeny of Callblepharis saidana}

Our nuclear SSU sequence dataset included 24 sequences from 10 genera of the Cystocloniaceae and two outgroup genera of the order Gigartinales (Fig. 5). The ML and BI trees based on SSU sequences were identical and two specimens of $C$. saidana collected in Korea and Japan were also identical. The clade that included Hypnea was strongly supported $(\mathrm{MLBt}=100 / \mathrm{BPP}=1.0)$, but Calliblepharis was not monophyletic. To our surprise, C. saidana formed a group with five species of Calliblepharis, including the type species C. ciliata (AY437668), support values $=59 / 0.88$. Interestingly, C. planicaulis (AY437670) was more closely related to the Hypnea clade, support values $=75 / 0.97$ than to Callblepharis .

The plastid $r b c \mathrm{~L}$ sequence dataset comprised 41 sequences representing six genera from the Cystocloniace- 


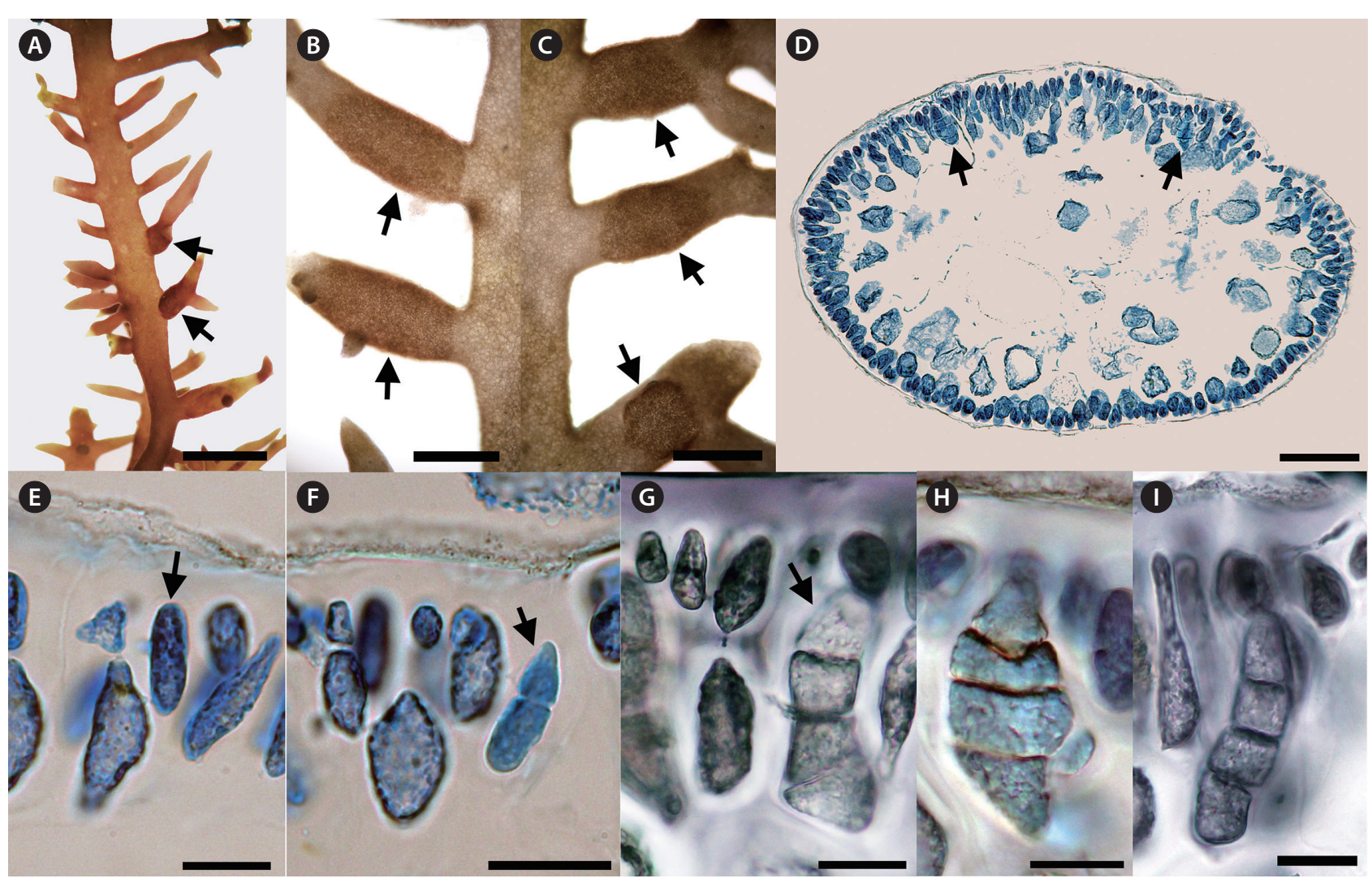

Fig. 4. Tetrasporangia of Calliblepharis saidana comb. nov. (voucher $=135,533$ ). (A-C) Tetrasporangial sori (arrows) on basal or middle portions of short branchlets. (D) Cross-section of a tetrasporangial sorus showing tetrasporangia (arrows) immersed in the cortex. (E) Tetrasporangial primordium (arrow) differentiating in a modified cortical cell with a pit connection. (F) First division to form two cells (arrow) with a pit connection to its bearing cell. (G) Formation of tetraspores (arrow) through successive rounds of zonate division with a pit connection to its bearing cell. ( $\mathrm{H} \& \mathrm{l}$ ) Mature tetrasporangia of varying morphology. Scale bars represent: A, $2 \mathrm{~mm}, \mathrm{~B} \& \mathrm{C}, 1 \mathrm{~mm} ; \mathrm{D}, 100 \mu \mathrm{m} ; \mathrm{E} \& \mathrm{G}-\mathrm{I}, 20 \mu \mathrm{m} ; \mathrm{F}, 30 \mu \mathrm{m}$.

ae and three outgroup genera from the Areschoiugiaceae of the order Gigartinales. The ML and BI trees constructed from $r b c$ L sequences of the Cystocloniaceae were also identical (Fig. 6). All $r b c \mathrm{~L}$ sequences from 21 specimens of C. saidana collected at 15 sites around Korea and Japan were identical as well. Twenty species of Hypnea were well clustered, but C. saidana was not included in the Hypnea clade again. Rather, C. saidana was consistently placed between C. fimbriata (AF385654) and a clade consisted four other Calliblepharis species with the type species $C$. cilata (KC121116).

The ML and BI using the combined alignment of SSU and $r b c \mathrm{~L}$ sequences yielded almost concordant tree, with little difference at node (Fig. 7). The combined tree resolved monophyletic node of the genus Calliblepharis including type species, C. ciliata, even though the node was supported by low bootstrap values. C. saidana formed weak sister relationships with C. fimbriata and C. celatospora.

Based on our morphological and molecular data, we conclude C. saidana is more closely related to the genus Calliblepharis than to the genus Hypnea and propose a new combination:

Calliblepharis saidana (Holmes) M. Y. Yang \& M. S. Kim comb. nov.

Basionym. Hypnea saidana Holmes 1895: 256 [New marine algae from Japan. J. Linn. Soc. Lond. Bot. 31:248260, 6 plates].

Type locality. Enoshima, Japan (Holmes 1895).

\section{DISCUSSION}

Calliblepharis saidana has been assigned to the genus Hypnea since its first description because it resembles members of the genus Hypnea superficially: it has uniaxial, cartilaginous thalli, alternate branches with short branchlets, rounded medullary cells surrounding 


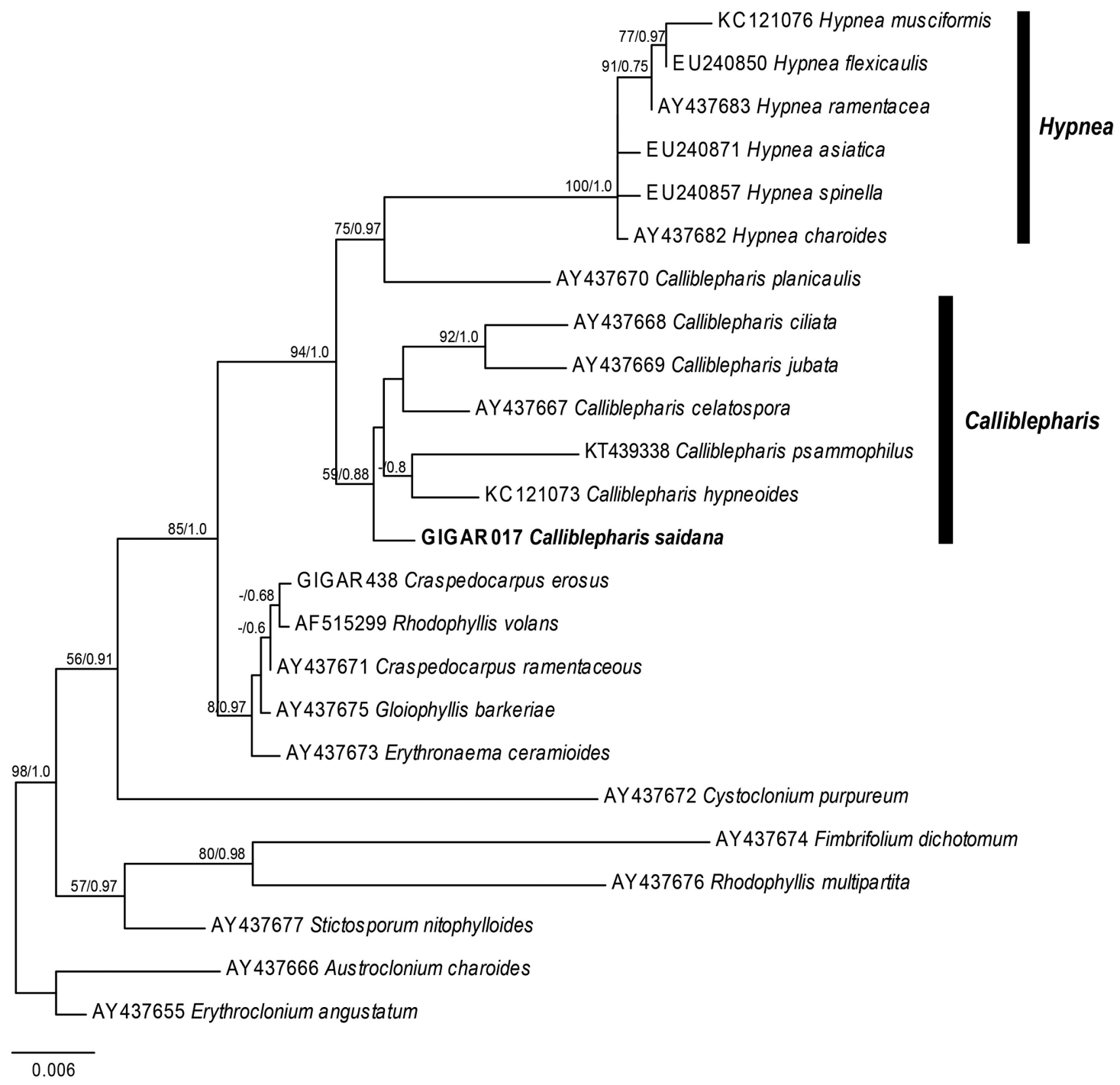

Fig. 5. The maximum likelihood phylogeny of Calliblepharis saidana comb. nov. based on the nuclear small subunit rDNA sequences data (-InL $=4,548.176818$ ). Support values shown on branches are maximum likelihood bootstrap (MLBt) and Bayesian posterior probability. MLBt values of $<50 \%$ are indicated by hyphens (-). The sequence in bold was generated in this study.

the central axial filaments, and zonately divided tetrasporangia (Holmes 1895, Okamura 1909, Tanaka 1941). However, with the continued refinement of conventional morphology-based taxonomic approach and the introduction of novel molecular analysis-based methodology, the red algal taxonomy, especially between Hypnea and Calliblepharis of the order Gigartinales, has undergone substantial restructuring recently and the need for reassessing C. saidana has been raised. For instance, the feature of a complanate thallus in vegetative morphology suggested a relationship with Calliblepharis which typically has compressed or flattened thallus (Min-Thein and Womersley 1976, Shin and Boo 1994). Furthermore, there were reports on Calliblepharis species having completely terete thallus as well: C. hypneoides and C. psammophilus collected from the Atlantic Iberian Peninsula and New Zealand, respectively (Díaz-Tapia et al. 2013, D’Archino et al. 2015).

Our molecular analyses using sequences of both SSU and $r b c \mathrm{~L}$ demonstrated the phylogenetic position of $C$. saidana within the family Cystocloniaceae. The combined tree derived from SSU and $r b c \mathrm{~L}$ alignments showed that C. saidana was grouped with the clade including the type species C. ciliata. They shared inner structure, an axial filament with surrounding elongated periaxial cells (Díaz-Tapia et al. 2013). The structure such as periaxial 


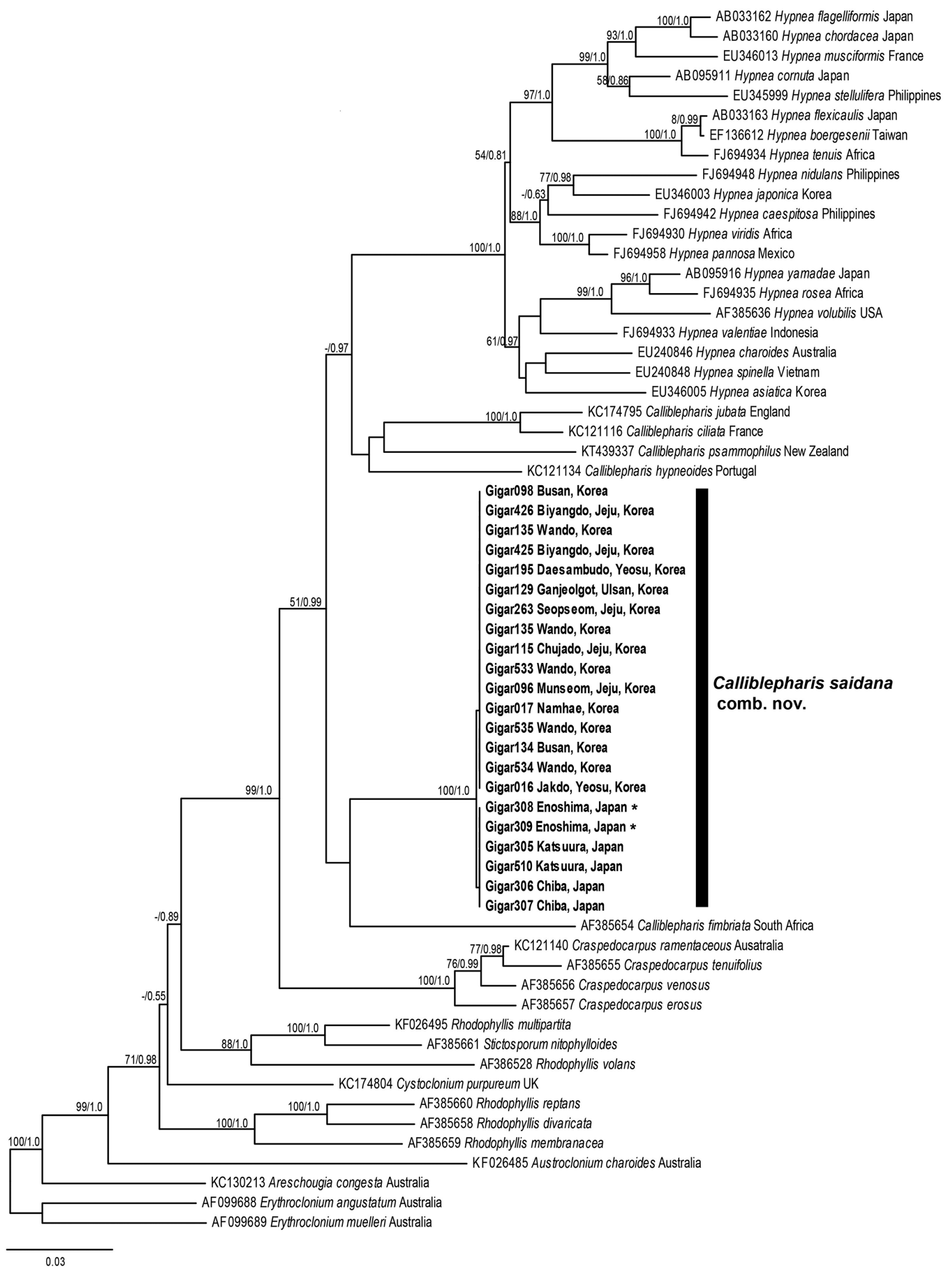

Fig. 6. The maximum likelihood phylogeny of Calliblepharis saidana comb. nov. based on the plastid rbcL data (-InL $=9,663.853378)$. Support values shown on branches are maximum likelihood bootstrap (MLBt) and Bayesian posterior probability from DNA data. MLBt values of $<50 \%$ are indicated by hyphens (-). Sequences in bold were generated in this study. Asterisk means specimens from type locality. 


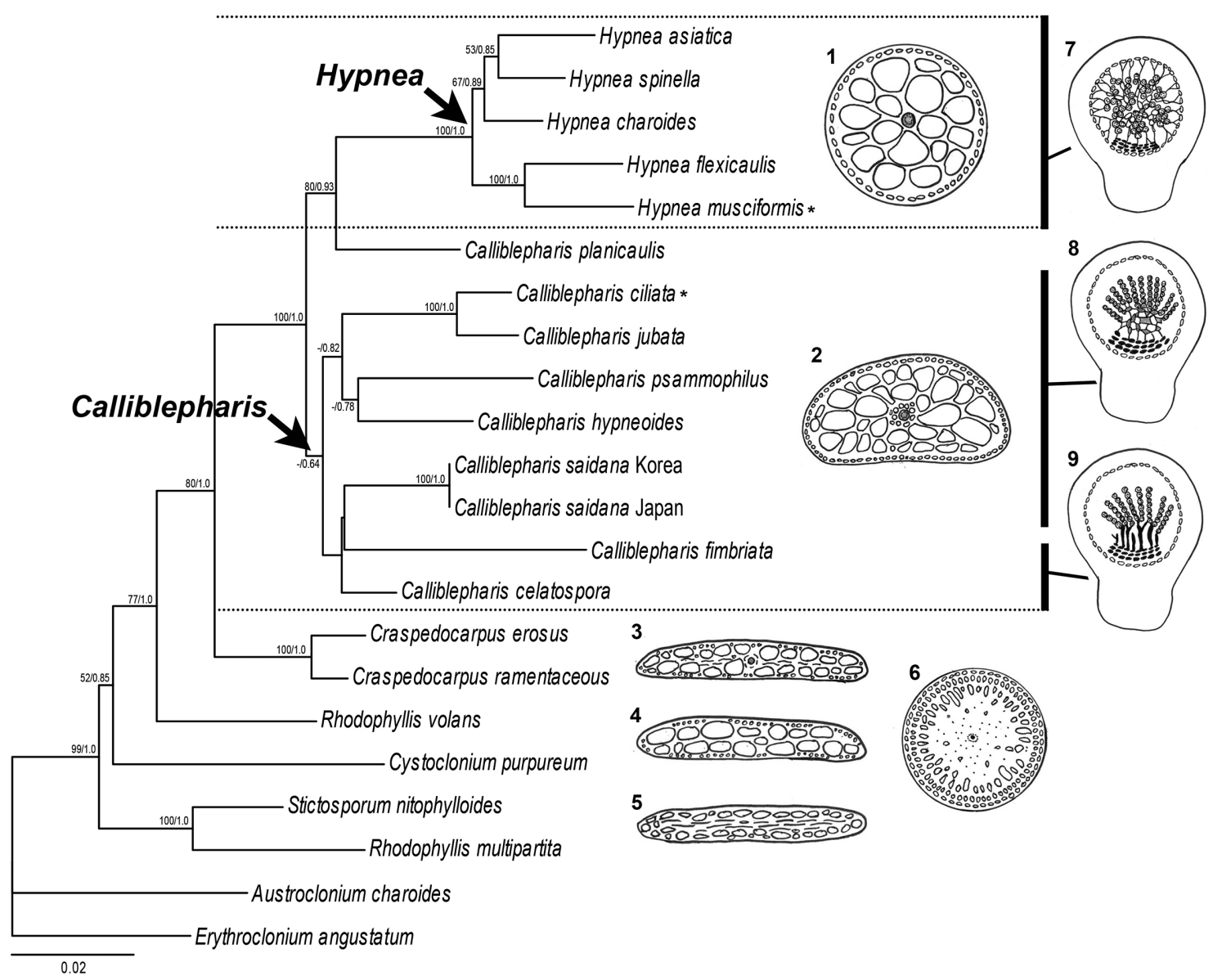

Fig. 7. The maximum likelihood phylogeny of Calliblepharis saidana comb. nov. derived from combined alignment ( $r b c L$ and SSU rDNA). Support values shown on branches are maximum likelihood bootstrap (MLBt) and Bayesian posterior probability from DNA data. MLBt values of $<50 \%$ are indicated by hyphens (-). Asterisk means the type species of Hypnea and Calliblepharis. To right of tree, diagrams of cross section of the vegetative thallus (1-6) and female cystocarp structures (7-9) for the family Cystocloniaceae. 1. Axial cell with medullary cells in the genus Hypnea. 2. Axial cell surrounded by several periaxial cells and medullary cells in the genus Calliblepharis. 3. Axial cell surrounded by periaxial cells and medullary cells with some rhizoidal filaments in the genus Craspedocarpus. 4. Axial cell with medullary cell in the genus Rhodophyllis. 5. Inconspicuous axial cell and medulla of elongated cells with rhizoids in the genus Stictosporum. 6. Axial cell and medulla of elongated cells with rhizoids in the genus Austroclonium. 7. Single carposporangia and numerous filaments connecting the gonimoblast and the pericarp in the genus Hypnea. 8. Chains of carposporangia and reticulum of gonimoblast filaments in the Calliblepharis species including type species and C. saidana. 9. Chains of carposporangia and parallel columns of gonimoblast filaments in C. fimbriata and C. celatospora.

filaments of main axis is a synapomorphic feature of the genus Calliblepharis but it is absent in other genera of Cystocloniaceae as well as most species of Hypnea (Table 1) (Kylin 1930, Tanaka 1941, Díaz-Tapia et al. 2013). Other genera such as Craspedocarpus, Rhodophyllis, Cystoclonium, and Stictosporum have an axial cell surrounding by medullary cell and frequently have rhizoidal filaments in medulla (Fig. 7) (Min-Thein and Womersley 1976). The rhizoidal filaments are absent in both genera Calliblepharis and Hypnea. The genus Craspedocarpus is similar with Calliblepharis in having several periaxial filaments surrounding axial cell, but Craspedocarpus differs by its rhizoids in the medulla and well developed rosette in cor- tical cells (Womersley 1994).

Contrary to thallus morphology, female reproductive structures reliably discriminate Calliblepharis from Hypnea despite their convoluted taxonomic history. Both genera were originally placed in the family Hypneaceae because of the procarp structure (Kylin 1930). Calliblepharis was later moved to the family Cystocloniaceae (as Rhodophyllidaceae) based on the female reproductive structures (Kylin 1932). However, Hypneaceae and Cystocloniaceae were recently merged based on the phylogenetic analysis of SSU sequences (Saunders et al. 2004), putting Calliblepharis and Hypnea in the same family again. Notwithstanding, Calliblepharis is readily distin- 


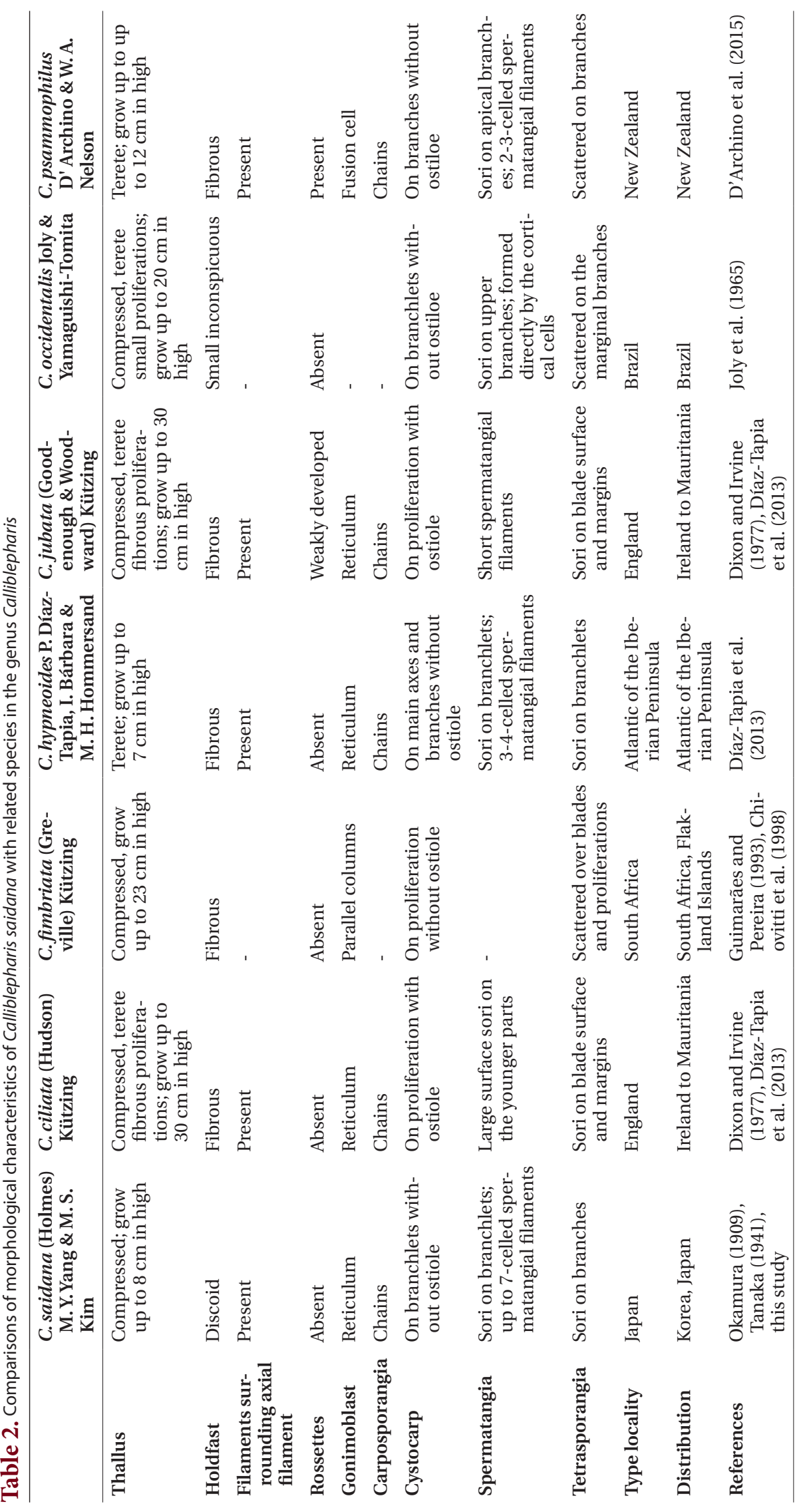


guished from Hypnea by its female structures (Fig. 7) (Kylin 1928, 1930) and by its molecular phylogeny (DíazTapia et al. 2013, D'Archino et al. 2015). The central clusters of cystocarps in Calliblepharis congeners either form a reticulum or arrange themselves into parallel columns (Chiovitti et al. 1998, Díaz-Tapia et al. 2013). C. saidana and the type species C. ciliata (Díaz-Tapia et al. 2013) have reticula, but Hypnea congeners lack this structure. On the other hand, central clusters of cells without large fusion cells have been observed previously in Calliblepharis and Hypnea (Hommersand and Fredericq 1990, Chiovitti et al. 1998, Díaz-Tapia et al. 2013, Vázquez-Delfín et al. 2016). The clusters of small cells produce radial gonimoblast filaments, each of which bears only one terminal carposporangium in Hypnea (Kylin 1930, Vázquez-Delfín et al. 2016), while that in Calliblepharis bears a chain of carposporangia at the end as shown in this study for $C$. saidana. Finally, gonimoblasts generate elongated filaments attached to the pericarp and placenta (Kylin 1930, Vázquez-Delfín et al. 2016) in Hypnea while no such cells were observed in Calliblepharis. C. psammophilus is an interesting exception in that it possesses a central fusion cell develops chains of gonimoblast filaments (D'Archino et al. 2015). The post-fertilization events of C. psammophilus should be further analyzed in detail. In the combined tree, C. saidana was sister with C. fimbriata and C. celatospora even though the clade was weakly supported. These two sister species have gonimoblasts in a series of parallel column oriented placenta in distinct from C. saidana and C. ciliata (Chiovitti et al. 1998). This gonimoblast characteristics were considered the possibility for creating a new genus (Chiovitti et al. 1998), but it was still unresolved in this study, meaning that a wider taxon sampling is necessary to infer the phylogenetic relationships in the genus Calliblepharis. Interestingly, Calliblepharis planicaulis was positioned between two genera, Calliblepharis and Hypnea, as found previously (Saunders et al. 2004, DíazTapia et al. 2013). Combined results of molecular data and female structures of C. planicaulis (chains of carposporangia in Calliblepharis-type and filaments between gonimoblast and pericarp in Hypnea-type) (Min-Thein and Womersley 1976) were raised an intriguing taxonomic questions about generic relationship which is required additional discussion in future study.

The male structure of $C$. saidana was quite distinct from those of its congeners (Table 2). C. saidana formed spermatangial sori on branchlets. The spermatangia cleaved off from a spermatangial mother cell that had differentiated from a cortical cell, and formed transversely divided spermatial filaments of up to seven rounded cells. This is longer than those of C. hypneoides and C. psammophilus (Díaz-Tapia et al. 2013, D’Archino et al. 2015). C. saidana exhibited distinctive antheridial walls in the mature spermatangium. This lead to the accumulation of spermatia in one place before their release in C. saidana, which is the first observation in the family Cystocloniaceae. Piled up spermatia of $C$. saidana were then released en masse from the antheridial wall unlike other species in Cystolonicaceae where single spermatium was released (Min-Thein and Womersley 1976, Díaz-Tapia et al. 2013, D'Archino et al. 2015).

Gametophytes of Hypnea have rarely been found in the wild. Reis and Yoneshigue-Valentin (2000) even claimed that sexual reproduction in these plants has been replaced by asexual and vegetative forms of reproduction, perhaps as a strategy, to survive under difficult environmental conditions. We were very fortunate to collect specimens having female and male reproductive structures that provided morphological evidence supporting our molecular analysis. Our combination of morphological and molecular approaches strongly suggested new taxonomic entity that can extend the understanding of this group. Apparently, further information on the reproductive structures and molecular studies of other species in Calliblepharis are required to improve our knowledge on the phylogenetic relationships within this group. Introducing C. saidana in this study, we expand the range of Calliblepharis habitat to the northwestern Pacific (Korea and Japan) from the eastern Atlantic, South Africa, the northern Indian Ocean, Australasia, and Brazil.

\section{ACKNOWLEDGEMENTS}

We thank Dr. Kikuchi for helping us during our sample collection trips to Japan and members of the Molecular Phylogeny of Marine Algae Laboratory at Jeju National University. This work was supported by a grant from the National Institute of Biological Resources (NIBR), funded by the Ministry of Environment (MOE) of the Republic of Korea (NIBR201722202 for the Graduate Program of the Undiscovered Taxa from Korea, and NIBR201501209 for collecting samples). 


\section{REFERENCES}

Calderon, M. S. \& Boo, S. M. 2016. Phylogeny of Phyllophoraceae (Rhodophyta, Gigartinales) reveals Asterfilopsis gen. nov. from the Southern Hemisphere. Phycologia 55:543-554.

Chiovitti, A., Kraft, G. T., Bacic, A., Craik, D. J., Munro, S. L. A. \& Liao, M. -L. 1998. Carrageenans from Australian representatives of the Family Cystocloniaceae (Gigartinales, Rhodophyta), with description of Calliblepharis celatospora sp. nov., and transfer of Austroclonium to the Family Areschougiaceae. J. Phycol. 34:515-535.

D’Archino, R., Nelson, A., Yang, M. Y. \& Kim, M. S. 2015. New record of Hypnea flexicaulis in New Zealand and description of Calliblepharis psammophilus sp. nov. Bot. Mar. 58:485-497.

Díaz-Tapia, P., Boo, S. M., Geraldino, P. J. L., Maneiro, I., Bárbara, I. \& Hommersand, M. H. 2013. Morphology and systematics of Calliblepharis hypneoides, sp. nov. (Cystocloniaceae, Rhodophyta) from the Atlantic Iberian Peninsula. Eur. J. Phycol. 48:380-397.

Dixon, P. S. \& Irvine, L. M. 1977. Seaweeds of the British Isles. Vol. 1. Rhodophyta. Part 1. Introduction, Nemaliales, Gigartinales. British Museum (Natural History), London, $252 \mathrm{pp}$.

Gavio, B. \& Fredericq, S. 2002. Grateloupia turuturu (Halymeniaceae, Rhodophyta) is the correct name of the nonnative species in the Atlantic known as Grateloupia doryphora. Eur. J. Phycol. 37:349-359.

Geraldino, P. J. L., Riosmena-Rodriquez, R., Liao, L. M. \& Boo, S. M. 2010. Phylogenetic relationships within the genus Hypnea (Gigartinales, Rhodophyta), with a description of $H$. caespitosa sp. nov. J. Phycol. 46:336-345.

Geraldino, P. J. L., Yang, E. C., Kim, M. S. \& Boo, S. M. 2009. Systematics of Hypnea asiatica sp. nov. (Hypneaceae, Rhodophyta) based on morphology and nrDNA SSU, plastid $r b c \mathrm{~L}$, and mitochondrial cox 1 . Taxon 58:606-616.

Guimarães, S. M. P. D. B. \& Pereira, A. P. V. 1993. Rhodofíceas marinhas bentônicas do estado do Espírito Santo, Brasil: gênero Calliblepharis (Cystocloniaceae, Gigartinales). Hoehnea 20:35-46.

Guiry, M. D. \& Guiry, G. M. 2017. AlgaeBase. World-wide electronic publication, National University of Ireland, Galway. Available from: http://www.algaebase.org. Accessed Feb 12, 2017.

Holmes, E. M. 1895. New marine algae from Japan. J. Linn. Soc. Lond. Bot. 31:248-260.

Hommersand, M. H. \& Fredericq, S. 1990. Sexual reproduction and cystocarp development. In Cole, K. M. \& Sheath, R. G. (Eds.) Biology of the Red Algae. Cambridge
University Press, Cambridge, pp. 305-346.

Hommersand, M. H., Fredericq, S., Freshwater, D. W. \& Hughey, J. 1999. Recent developments in the systematics of the Gigartinaceae (Gigartinales, Rhodophyta) based on $r b c \mathrm{~L}$ sequence analysis and morphological evidence. Phycol. Res. 47:139-151.

Joly, A. B., Cordeiro-Marino, M., Ugadim, Y., Yamaguishi-Tomita, N. \& Pinheiro, F. C. 1965. New marine algae from Brazil. Arq. Est. Biol. Mar. Univ. Ceará 5:79-92.

Kim, M. S., Kim, S. Y. \& Nelson, W. 2010. Symphyocladia lithophila sp. nov. (Rhodomelaceae, Ceramiales), a new Korean red algal species based on morphology and $r b c \mathrm{~L}$ sequences. Bot. Mar. 53:233-241.

Kylin, H. 1928. Entwicklungsgeschichtliche Florideenstudien. Lunds Univ. Ärsskr. 24:1-127.

Kylin, H. 1930. Über die Entwicklungsgeschichte der Florideen. Lunds Univ. Ärsskr. 26:1-104.

Kylin, H. 1932. Die Florideenordnung Gigartinales. Lunds Univ. Ärsskr. 28:1-88.

Lin, S. -M., Hommersand, M. H., Fredericq, S. \& De Clerck, O. 2009. Characterization of Martensia (Delesseriaceae, Rhodophyta) based on a morphological and molecular study of the type species, M. elegans, and M. natalensis sp. nov. from South Africa. J. Phycol. 45:678-691.

Min-Thein, U. \& Womersley, H. B. S. 1976. Studies on southern Australian taxa of Solieriaceae, Rhabdoniaceae and Rhodophyllidaceae (Rhodophyta). Aust. J. Bot. 24:1-166.

Mshigeni, K. E. 1976. Studies on the reproduction of selected species of Hypnea (Rhodophyta, Gigartinales) from Hawaii. Bot. Mar. 19:341-346.

Okamura, K. 1909. Icones of Japanese algae. Vol. II. Plates LVILX. Published by the author, Tokyo, pp. 21-40.

Reis, R. P. \& Yoneshigue-Valentin, Y. 2000. Phenology of Hypnea musciformis (Wulfen) Lamouroux (Rhodophyta, Gigartinales) in three populations from Rio de Janeiro State, Brazil. Bot. Mar. 43:299-304.

Ronquist, F., Teslenko, M., van der Mark, P., Ayres, D. L., Darling, A., Höhna, S., Larget, B., Liu, L., Suchard, M. A. \& Huelsenbeck, J. P. 2012. MrBayes 3.2: efficient Bayesian phylogenetic inference and model choice across a large model space. Syst. Biol. 61:539-542.

Saunders, G. W., Chiovitti, A. \& Kraft, G. T. 2004. Smallsubunit rRNA gene sequences from representatives of selected families of the Gigartinales and Rhodymeniales (Rhodophyta). 3. Delineating the Gigartinales sensu stricto. Can. J. Bot. 82:43-74.

Saunders, G. W. \& Moore, T. E. 2013. Refinements for the amplification and sequencing of red algal DNA barcode and RedToL phylogenetic markers: a summary of current primers, profiles and strategies. Algae 28:31-43. 
Sherwood, A. R., Kurihara, A., Conklin, K. Y., Sauvage, T. \& Presting, G. G. 2010. The Hawaiian Rhodophyta biodiversity survey (2006-2010): a summary of principal findings. BMC Plant Biol. 10:258.

Shin, W. G. \& Boo, S. M. 1994. A systematic study on the genus Hypnea (Gigartinales, Rhodophyta) in Korea. Korean J. Phycol. 9:7-20.

Sievers, F., Wilm, A., Dineen, D., Gibson, T. J., Karplus, K., Li, W., Lopez, R., McWilliam, H., Remmert, M., Söding, J., Thompson, J. D. \& Higgins, D. G. 2011. Fast, scalable generation of high-quality protein multiple sequence alignments using Clustal Omega. Mol. Syst. Biol. 7:539.

Stamatakis, A. 2006. RAxML-VI-HPC: maximum likelihoodbased phylogenetic analyses with thousands of taxa and mixed models. Bioinformatics 22:2688-2690.

Tanaka, T. 1941. The genus Hypnea from Japan. Sci. Pap. Inst. Algol. Res. Fac. Sci. Hokkaido Imp. Univ. 2:227-250.

Vázquez-Delfín, E., Boo, G. H., Rodríguez, D., Boo, S. M. \& Robledo, D. 2016. Hypnea musciformis (Cystocloniaceae) from the Yucatan Peninsula: morphological variability in relation to life-cycle phase. Phycologia 55:230-242.

Wittmann, W. 1965. Aceto-iron-haematoxylin-chloral hydrate for chromosome staining. Stain Technol. 40:161-
164.

Womersley, H. B. S. 1994. The marine benthic flora of southern Australia. Part IIIA. Bangiophyceae and Florideophyceae (Acrochaetiales, Nemaliales, Gelidiales, Hildenbrandiales and Gigartinales sensu lato). Australian Biological Resources Study, Canverra, 508 pp.

Won, B. Y., Jeong, S. Y. \& Cho, T. O. 2016. Morphology and phylogeny of Craspedocarpus jindoensis sp. nov. (Cystocloniaceae, Gigiartinales) from Korea. Phycologia 55:611-618.

Yamagishi, Y. \& Masuda, M. 1997. Species of Hypnea from Japan. In Abbott, I. A. (Ed.) Taxonomy of Economic Seaweeds: With Reference to Some Pacific Species. Vol. 6. California Sea Grant College Program, La Jolla, CA, pp. 135-162.

Yang, M. Y. \& Kim, M. S. 2016. Molecular phylogeny of the genus Chondracanthus (Rhodophyta), focusing on the resurrection of $C$. okamurae and the description of $C$. cincinnus sp. nov. Ocean Sci. J. 51:517-529.

Yang, M. Y., Macaya, E. C. \& Kim, M. S. 2015. Molecular evidence for verifying the distribution of Chondracanthus chamissoi and C. teedei (Gigartinaceae, Rhodophyta). Bot. Mar. 58:103-113. 